УДК 316.77:378.02:658.5

DOI: https://doi.org/10.32851/2708-0366/2021.10.9

Маковецька I.M.

кандидат економічних наук,

Державний університет телекомунікацій

ORCID: https://orcid.org/0000-0001-6219-8276

Makovetska Iryna

State University of Telecommunications

\title{
КОМУНІКАЦІЙНИЙ ВЕКТОР НАЛАГОДЖЕНИХ ІНФОРМАЦІЙНИХ ПРОЦЕСІВ ДЛЯ ЕФЕКТИВНОГО УПРАВЛІННЯ ПІДПРИЄМСТВОМ
}

\section{COMMUNICATION VECTOR OF WELL-ESTABLISHED INFORMATION PROCESSES FOR EFFECTIVE ENTERPRISE MANAGEMENT}

У статті розглянуто вплив інформаційних прочесів на ефективність управління підприємством та розкрито комунікаційний вектор досягнення позитивних результатів інформації, яка надається працівникам підприємства. Наголошено, шо без новітніх технологій неможливо поліпшити ефективність роботи на підприємстві. Представлено види інформаційних зв'язків із працівниками для ефективної роботи підприємства, завдяки чому закладається успішний комунікаційний потенціал на підприємстві. Досліджено переваги підприємства, щуо використовують у своїй діяльності новітні інформаційні технологї. Описано основні вектори налагоджених інформаційних процесів для ефективного управління підприємством, щуо забезпечують продуктивність управлінських відносин та вихід на глобалізаційний комунікаційний простір.

Ключові слова: комунікація, інформація, інформаційні прочеси, вектор, підприємство, ефективність.

В статье рассмотрено влияние информационных процессов на эффективность управления предприятием и раскрыт коммуникационный вектор достижения положительных результатов информации, предоставляемой работникам предприятия. Отмечено, что без новейших технологий невозможно улучшить эффективность работь на предприятии. Представлены виды информачионных связей с работниками для эффективной работы предприятия, благодаря чему закладывается успешный коммуникаиионный потенииал на предприятии. Исследованы преимущества предприятия, использующего в своей деятельности новейшие информационные технологии. Описаны основные векторы отлаженных информационных прочессов для эффективного управления предприятием, которые обеспечат производительность управленческих отночений и выход в глобализациионное коммуникациионное пространство.

Ключевые слова: коммуникация, информация, информационные процессы, вектор, предприятие, эффективность.

The article considers the impact of information processes on the efficiency of enterprise management and reveals the communication vector of achieving positive results of information provided to employees. It is emphasized that without the latest technologies it is impossible to improve the efficiency of work at the enterprise. It was found that important for the disclosure of the communication vector is the information potential of the enterprise, which is understood as a set of information resources and capabilities for their implementation, providing conditions for development based on the acquisition, accumulation and use of knowledge. The types of information connections with employees are presented for the effective work of the enterprise, according to which the successful communication potential of the enterprise is established. It is established that the creation of effective communications both inside and outside the company is achieved through a well-organized communication process. In order to achieve high quality and effective management, all participants in the process must have equal access to information resources. The advantages of the enterprise which use the newest information technologies in the activity are investigated. The main vectors of well-established information 
processes for effective enterprise management are described, which will ensure the productivity of management relations and access to the globalization communication space. It is substantiated that the communication vector of information processes in enterprises has led to the introduction and development of informatization and communications, which may contain different numbers of qualitative and quantitative characteristics of the enterprise itself. It is proved that in order to increase the effective management of the enterprise, communications are involved, where it is necessary to clearly send data and demonstrate their understanding to employees, coordinate information processes between departments and simplify their information exchange schemes. That's right, then the potential of the communication vector will be revealed with selected ways to implement effective communications in the enterprise.

Key words: communication, information, information processes, vector, enterprise, efficiency.

Постановка проблеми. Сьогоднішне інформаційне суспільство використовує у своїй діяльності новітні інформаційні технології в усіх сферах економічного розвитку для більш насиченого регулювання інформаційних процесів на підприємствах. Саме тому створення інформаційних технологій не лише для поліпшення ефективної роботи на підприємствах різної форми власності, а й і ведення бізнесу в Україні 3 кожним роком зумовлює глобальне використання інформатизації та комунікацій, що визначає рівень інноваційного відношення інформаційного суспільства за допомогою усталених наукових парадигм. Проте спрямованість комунікаційного вектора налагоджених інформаційних процесів набуває нових розширених горизонтів та відкриттів у виробничій структурі управління інформаційною системою, але ця проблематика потребує подальших досліджень на підприємствах.

Аналіз останніх досліджень і публікацій. Розвиток сучасних комунікацій на підприємстві знайшов своє відображення у працях таких учених, як: О.У. Безчасний, І.В. Бойчук, В.Г. Герасимчук, Л.К. Гліненко, Н.Л. Любченко, В.М. Орел, Т.О. Примак, Л.Р. Прус, Л.Ю. Сагер, Л.А. Шергіна та ін. О. Бухтатий, О. Радченко, Г. Головченко здійснили дослідження комунікаційних процесів у сучасній Україні [3]. Разом із тим безліч аспектів науковцями залишаються недостатньо висвітленими, потрібно розвивати та використовувати сучасні комунікаційні технології на підприємстві відповідно до реальних умов розвитку ринку.

Формулювання цілей статті. Метою статті $\epsilon$ визначення впливу інформаційних процесів на роботу працівників та розкриття комунікаційних векторів з урахуванням їхніх особливостей прогресивного впливу на ефективність підприємства.

Виклад основного матеріалу. Формат інформаційно-комунікаційної діяльності доволі складний під час вибору нових важелів управління на підприємстві. Для системи налагоджених інформаційних процесів на підприємствах характерні події, що об’єднують та пов'язують дану структуру управління у єдине ціле.

Комунікаційний вектор інформаційних процесів на підприємствах призвів до запровадження та розвитку інформатизації та комунікацій, що можуть містити різну кількість якісних та кількісних характеристик самого підприємства.

Технологічно-інформаційним складником системи зв'язку на підприємстві $€$ iï інструментальна частина, яка забезпечує автоматизацію обміну інформацією між працівниками та відділами підприємства. Основними елементами $є$ апаратне, програмне забезпечення та канали зв'язку. Кожен із цих елементів має певні техніко-економічні характеристики, що визначають ефективність цього комунікаційного компонента як вектора налагоджених інформаційних процесів для ефективного управління підприємством через систему зв'язків між ними [7, с. 40].

Важливим для розкриття комунікаційного вектора $є$ інформаційний потенціал підприємства, який розуміють як сукупність інформаційних ресурсів і спроможностей до ïx реалізації, що забезпечують умови розвитку на основі отримання, накопичення та використання знань. До інформаційного потенціалу потрібно включати інформаційні, інтелектуальні та інші активи, що включають знання і досвід працівників; технічну 
документацію; права власності на інтелектуальну продукцію; програмне, інформаційне та інше забезпечення обчислювальних інформаційних систем; наукомісткі послуги, технології; засоби зв'язку та комунікації, інформаційні системи управління; імідж корпорації [9, с. 13].

Комунікаційний вектор ефективного управління підприємством пролягає через реалізацію інформаційних процесів. Дуже важливим для підприємства, яке працює в умовах економічного росту, виступає його сайт, де всі зацікавлені сторони можуть переглянути та отримати різну корисну інформацію про підприємство. Здебільшого комунікаційний вектор налагоджених інформаційних процесів можна розбити на три групи донесення інформації працівникам на підприємстві (рис. 1).

Якщо правильно буде окреслений комунікаційний вектор, то і працівники зможуть провести інформацію по комунікаційному каналу так, щоб вона мала становити всю сукупність інноваційних пристроїв і програм, призначених для зберігання, опрацювання, подання та передавання даних на підприємстві.

Водночас на підприємстві повинні бути забезпечені достатні мобільність та швидкість обміну інформацією, мінімальні втрати та спотворення цих інформаційних даних, а особливу увагу приділяти потрібно необхідному рівню безпеки конфіденційних даних [5, с. 85].

Розглядаючи підприємства України, можна виділити три комунікаційні вектори налагоджених інформаційних процесів для ефективного управління підприємством.

Перший вектор набув масштабів ще в XX ст., коли підприємства стали цікавитися домінантним збільшенням кількості як потенційних клієнтів, так і кваліфікованих працівників. Під впливом комплексу різноманітних соціальних, технологічних, інформаційних та економічних чинників підприємствам знадобилися нові засоби забезпечення зв'язку для ефективної роботи працівників та налагодженої співпраці з клієнтами.

Координати можливостей сучасних технічних засобів, які утворюють інформаційно-комунікаційні мережі й системи, за останні тридцять років суттєво розширили світ, радикально змінили уявлення про інформаційно-комунікаційну діяльність, а іiі цифровізація взагалі, підвищуючи вимоги до неї, інтернаціоналізувала й уніфікувала стандарти, переводячи людський розвиток на новий щабель [6].

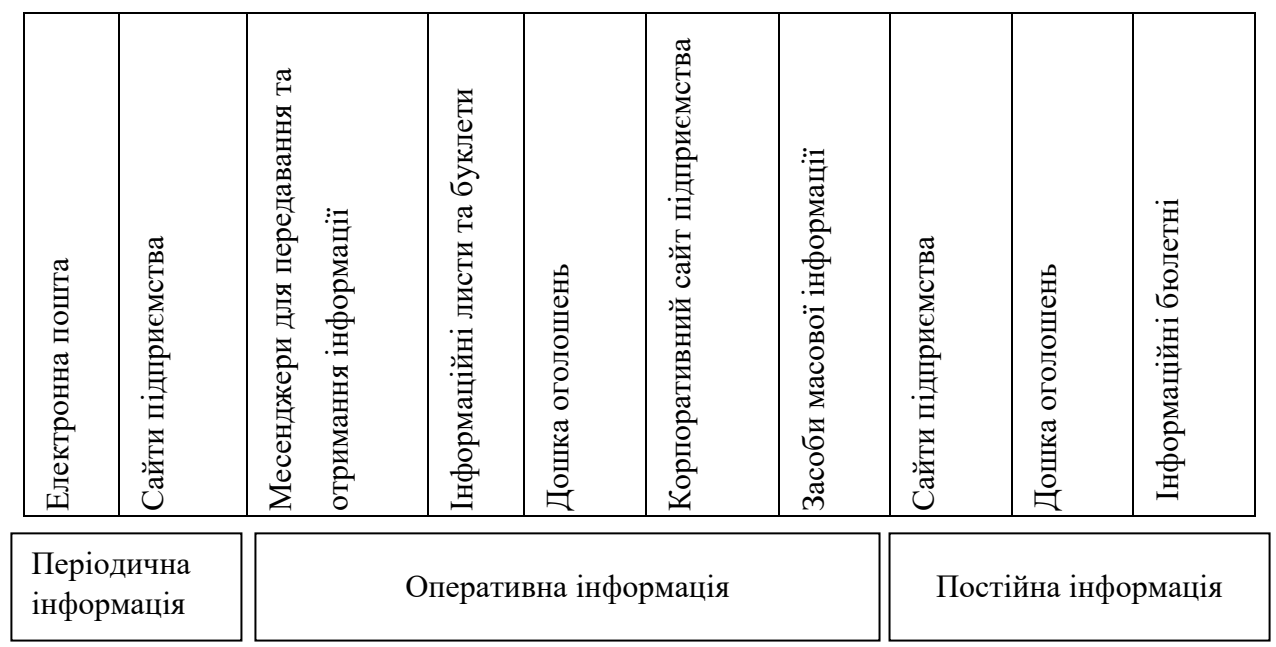

Рис. 1. Комунікаційний вектор зв'язків із працівниками через надану інформацію для ефективної роботи підприємства

Джерело: складено авторами на основі [4; 6; 8; 9] 
Саме завдяки ефективному комунікаційному вектору підприємства зможуть отримати такі переваги у своїй діяльності, як:

1. формування та підтримка відповідного іміджу підприємства на ринку, на якому вони працюють;

2. налагодження та підтримка зворотного зв'язку підприємства;

3. своєчасне отримання необхідної інформації від керівництва про ситуацію на ринку, передбачення змін у мікро- та макросередовищі;

4. формування власного організаційного, інтелектуального та технологічного потенціалу, здатного допомогти підприємству зберегти бажане становище у наявній ситуації на ринку;

5. посилення конкурентних переваг підприємства на ринку [4].

Другий вектор описує розвиток новітніх комп'ютерних інформаційних технологій, де на центральне місце на підприємстві вийшла тенденція до обсягу змісту інформаційних продуктів, які надають працівники. Тут головним завданням, яке стояло перед підприємством, було впровадження цифрових послуг для налагоджених інформаційних процесів.

Завдяки можливостям Інтернету різко зростає мобільність комунікацій. Відповідно, зростає й ефективність підприємницької діяльності. Але процес використання та постачання Інтернет-інформації не є однозначно позитивним, проте залишається актуальним інформаційний простір для вироблення якісних продуктів. Інтернет дає змогу кожному підприємству оприлюднювати свої досягнення за повної відсутності експертних фільтрів [2].

Саме тому інформаційні процеси є важливим інструментом впливу на діяльність підприємства та на визначення комунікаційного вектору розвитку.

Окрім того, інформаційні технології, змінюючи способи управління підприємством, змінюють також і форму кінцевого результату. Суттєво збільшується вміст інформації для кінцевого результату і значно зростає частка продукування інформаційного продукту. Сучасні інформаційні та комунікаційні технології надали можливість користування всіма типами інформації, перетворивши ії на порівняно недорогий і наявний у достатній кількості чинник [11].

I останній комунікаційний вектор - це глобальна цифровізація штучного інтелекту 3 використанням інформаційних технологій для спрощеного передавання та отримання інформації працівниками на підприємстві. Саме за допомогою нового покоління всі інформаційні та комунікаційні системи перетворюються на продуктивну силу, яка показує, що задіяний штучний інтелект у налагоджених інформаційних процесах вирішує нові завдання технічного прогресу для ефективної роботи підприємства.

Створення ефективних комунікацій як усередині, так і за межами підприємства досягається шляхом добре організованого комунікаційного процесу. Для досягнення високої якості та результативності управління усі учасники процесу мають мати рівний доступ до інформаційних ресурсів, можливість безперешкодно та ефективно комунікувати один з одним, формуючи оптимальні умови для успішного прийняття рішень, вирішення конфліктів та організації спільної роботи команд [10, с. 195].

Для підвищення ефективного управління підприємством задіяні комунікації, де необхідно чітко направляти дані та демонструвати їх розуміння працівникам, координувати інформаційні процеси між відділами та спрощувати схеми обміну інформацією. Саме так буде розкритий потенціал комунікаційного вектора $з$ виокремленими шляхами здійснення ефективних комунікацій на підприємстві.

Попри це потрібно, перш за все, сконцентруватися не лише на продуктивності та відданості працівників підприємству, а й із внесенням до механізму підприємства внутрішніх комунікацій набагато більша ймовірність того, що співробітники долучаться до цінностей та цілей підприємства, пропонуючи зворотний зв'язок та нові ідеї [8, с. 131]. 
Формування та поліпшення розуміння підприємством завдань комунікаційного характеру проявляються через його напрям задіяння інформації як необхідної умови ефективного управління підприємством.

Інтенсивне розширення комунікаційного вектора налагоджених інформаційних процесів для ефективного управління підприємством стає загальновідомим і висвітленим для розуміння шляху інформаційно-комунікаційного середовища з урахуванням усіх принципів, методів та чинників. Унаслідок цього на підприємстві реалізується взаєморозуміння усіх основних та допоміжних організаційно-комунікаційних та економічно-управлінських процесів.

Не менш важливим є вектор, який спрямований на стратегічну зону підприємства, а саме на іiі комунікаційну стратегію, яку можна розглядати в контексті іiї застосування для ефективного управління. У цьому разі комунікаційна стратегія стає самостійним видом управління, що забезпечує роботу всіх відділів та дає змогу здійснювати всі можливі операції з інформацією, які приведуть підприємство до досягнення позитивних результатів у багатьох показниках їх ефективності [1].

Висновки. В умовах інтенсивного розвитку інформаційних технологій прискорюється комунікаційне застосування досягнення сучасних інформаційних технологій у співвідношенні до значення і ролі сучасного комунікаційного вектора налагоджених інформаційних процесів для ефективного управління підприємством. Саме оцінка сучасних тенденцій розвитку комунікаційної направленості на підприємстві все більше проявляється у його бізнес-середовищі. Тому вигідно досліджувати та розкривати нові горизонти ефективного управління підприємством, що будуть поєднувати у собі затребуваність комунікацій на ринку з ефективним використанням новітніх інформаційно-комп'ютерно-телекомунікаційних систем.

\section{Список використаних джерел:}

1. Betteke Van Ruler. Communication Theory: An Underrated Pillar on Which Strategic Communication Rests. International Journal of Strategic Communication. 2018. Vol. 12. DOI: https://doi.org/10.1080/1553 18X.2018.1452240

2. Броннікова Л.В. Комунікація в сучасній науці: нові засоби для виробництва знання. Наукові праиі Чорноморського державного університету імені Петра Могили комплексу «Києво-Могилянська академія». Серія «Філософія». 2015. Т. 257. Вип. 245. С. 38-42.

3. Бухтатий О. Україна медійна: на порозі інформаційної революції. Київ : Видавець Панасенко, 2015. $208 \mathrm{c}$.

4. Войнаренко С.М. Ключові фактори успіху в комунікаційній політиці підприємств. Вісник Хмельницького національного університету. Економічні науки. 2017. № 6. Т. 1. С. 231-233.

5. Кириченко С.О., Цвях П.В. Проблеми формування комунікацій на підприємстві. Агросвіт. 2020. № 12. С. 79-86.

6. Проблеми формування сучасної інформаційно-комунікаційної сфери держави. URL: https://lexinform.com.ua/dumka-eksperta/problemy-formuvannya-suchasnoyi-informatsijnokomunikatsijnoyi-sfery-derzhavy/ (дата звернення: 07.12.2021).

7. Прус Л.Р. Комунікаційний менеджмент. Вісник Хмельнищького національного університету. Економічні науки. 2018. № 1. С. 38-41.

8. Сагер Л.Ю. Аналіз теоретичних основ внутрішніх комунікацій як необхідної умови ефективного управління підприємством. Маркетинг і менеджмент інноваиій. 2011. № 1. С. 128-136.

9. Сазонець О.М., Качан О.І. Тенденції розвитку інформаційного бізнесу в країнах світу. Інвестиції: практика та досвід. 2017. № 16. С. 10-14.

10. Туріянська М.М. Комунікації в системі управління знаннями. Вісник економічної науки України. 2011. № 2. С. 194-196.

11. Шергіна Л.А. Інформаційний вектор системи управління корпорацією в умовах світових змін. Економіка підприємства: теорія та практика : зб. матеріалів VIII Міжнар. наук.-практ. конф. ДВНЗ «Київ. нац. екон. ун-т ім. Вадима Гетьмана», м. Київ, 12-13 жовтня 2020 р. Київ, 2020. C. $84-85$. 


\section{References:}

1. Betteke Van Ruler (2018) Communication Theory: An Underrated Pillar on Which Strategic Communication Rests. International Journal of Strategic Communication, vol. 12. DOI: https://doi.org/ 10.1080/1553 18X.2018.1452240.

2. Bronnikova L.V. (2015) Komunikatsiya v suchasniy nautsi: novi zasoby dlya vyrobnytstva znannya [Communication in modern science: new tools for the production of knowledge]. Scientific works of the Petro Mohyla Black Sea State University of the Kyiv-Mohyla Academy complex. Series: Philosoph, tom 257, vol. 245, pp. 38-42.

3. Buchtatyi O. (2015) Ukrayina mediyna: na porozi informatsiynoyi revolyutsiyi [Media Ukraine: on the threshold of the information revolution]. Kyiv: SVS Panasenko, p. 208. (in Ukrainian)

4. Vojnarenko S.M. (2017) Klyuchovi faktory uspikhu $v$ komunikatsiyniy politytsi pidpryyemstv [Key success factors in the communication policy of enterprises]. Visnyk Khmel'nyts'koho natsional'noho universytetu. Ekonomichni nauky, no. 6, vol. 1, pp. 231-233.

5. Kyrychenko S., Tsviakh P. (2020) Problemy formuvannya komunikatsiy na pidpryyemstvi [Problems of forming communications at enterprise]. Agrosvit, no. 12, pp. 79-86.

6. Problemy formuvannya suchasnoyi informatsiyno-komunikatsiynoyi sfery derzhavy [Problems of formation of the modern information and communication sphere of the state]. Available at: https://lexinform.com.ua/dumka-eksperta/problemy-formuvannya-suchasnoyi-informatsijno-komunikatsijnoyi-sfery-derzhavy/ (accessed 07 December 2021).

7. Prus L.R. (2018) Komunikatsiynyy menedzhment [Communication management]. Visnyk Khmel'nyts'koho natsional'noho universytetu. Ekonomichni nauky, no. 1, pp. 38-41.

8. Saher L.Yu. (2011) Analiz teoretychnykh osnov vnutrishnikh komunikatsiy yak neobkhidnoyi umovy efektyvnoho upravlinnya pidpryyemstvom [Analysis of the theoretical foundations of internal communications as a necessary condition for effective enterprise management]. Marketynh i menedzhment innovatsij, no. 1, pp. 128-136.

9. Sazonets' O.M., Kachan O.I. (2017) Tendentsiyi rozvytku informatsiynoho biznesu v krayinakh svitu [Trends in the development of information business in the world]. Naukovyy zhurnal «Investytsiyi: praktyka ta dosvid», no. 16, pp. 10-14.

10. Turiyans'ka M.M. (2011) Komunikacii' v systemi upravlinnja znannjamy [Communications are in control system by knowledge]. Visnyk ekonomichnoi' nauky Ukrai'ny, no. 2, pp. 194-196.

11. Sherhina L.A. (2020) Informatsiynyy vektor systemy upravlinnya korporatsiyeyu v umovakh svitovykh zmin [Information vector of corporate governance in global change]. Business economics: theory and practice: coll. materials VIII International. scientific-practical conf. SHEI Kyiv. nat. econ. univ. Vadym Hetman, Kyiv, pp. 84-85. (in Ukrainian) 